\title{
PAGET-SCHROETTER SYNDROME IN FEMALE WATER POLO PLAYER
}

Rodionovskaya SR $\otimes$, Torosian GG, Aksenova NV

Federal Research and Clinical Center for Children and Adolescents, FMBA of Russia, Moscow, Russia

This article describes a case of Paget-Schroetter syndrome in a female water polo player. The condition was associated with strenuous exercise. The initial treatment strategy was limited to a 14-day heparin regimen followed by a course of diosmin and sulodexide. The article discusses the high risk of post-thrombotic syndrome in this cohort of patients and the rationale for a surgical intervention.

Keywords: thrombosis, thrombolysis, Paget-Schroetter syndrome, sports

Author contribution: Rodionovskaya SR supervised the study, wrote and edited the manuscript; Torosian GG collected data for the study and compiled the reference list; Aksenova NV collected data for the study.

Compliance with ethical standards: the patient gave voluntary informed consent to participate in the study.

Correspondence should be addressed: Svetlana R. Rodionovskaya

Moskvorechye, 20, Moscow, 115409; rodionovskaya@mail.ru

Received: 15.01.2021 Accepted: 17.02.2021 Published online: 13.03.2021

DOI: $10.47183 /$ mes.2021.005

\section{СИНДРОМ ПЕДЖЕТА-ШРЕТТЕРА У ПАЦИЕНТКИ, ЗАНИМАЮЩЕЙСЯ ВОДНЫМИ ВИДАМИ СПОРТА}

\author{
С. Р. Родионовская $\bowtie$, Г. Г. Торосян, Н. В. Аксенова
}

Федеральный научный-клинический центр детей и подростков Федерального медико-биологического агентства, Москва, Россия

Представлен случай синдрома Педжета-Шреттера у пациентки, занимающейся водным поло. Развитие заболевания отмечено на фоне интенсивных физических нагрузок. Тактика ведения пациентки была ограничена консервативным методом лечения с применением двухнедельного курса гепарина и последующими курсами диосмина и солудексида. Рассмотрены вопросы высокого риска посттромбослебитического синдрома у данной категории пациентов, целесообразности применения хирургических методов лечения.

Ключевые слова: тромбоз, тромболизис, синдром Педжета-Шреттера, спорт

Вклад авторов: С. Р. Родионовская - общее руководство, написание и редактирование рукописи; Г. Г. Торосян - сбор информации, осормление списка литературы; Н. В. Аксенова - сбор информации.

Соблюдение этических стандартов: пациентка подписала добровольное информированное согласие на участие в исследовании.

$\triangle$ Для корреспонденции: Светлана Рафраиловна Родионовская

ул. Москворечье, д. 20, г. Москва, 115409; rodionovskaya@mail.ru

Статья получена: 15.01.2021 Статья принята к печати: 17.02.2021 Опубликована онлайн: 13.03.2021

DOI: $10.47183 /$ mes.2021.005

Vascular injuries of the upper extremity are rarely seen in athletes. However, sports involving extreme physical exertion, like baseball, water polo, hockey, and swimming, increase the risk of upper extremity deep vein thrombosis, also known as effort thrombosis, or Paget-Schroetter syndrome (PSS) [1].

PSS is axillosubclavian vein thrombosis provoked by repetitive strenuous exercise of the upper extremity. The condition was first described by the French anatomist Jean Cruveilhier in 1816. In 1875, Sir James Paget provided a detailed account of its clinical presentations. In 1894, Leopold von Schroetter discovered that vascular injury due to physical strain was a potential factor implicated in the etiology of the disease. In the Russian literature, PSS has been known as effort thrombosis since 1934 when it was described by Anton Pytel.

The pathogenesis of the disease is linked to excess strain on the subclavian vein associated with shoulder hyperadduction, abduction or external rotation that result in endothelial microtrauma with subsequent coagulation cascade activation. Because of muscle hypotrophy common for athletes, the space between the clavicle and the first rib is narrowed, exposing the vein to compression. In turn, chronic compression of the vein or its branches provokes aseptic phlebitis (obliterative or mural) commonly accompanied by mural thrombus formation [1, 2].

\section{Clinical case}

On July 3, 2019, patient L., a 17-year-old female athlete (10 years in professional water polo; training load of up to
6 h a day) was admitted to the Federal Research and Clinical Center for Children and Adolescents, FMBA, for edema in the left shoulder region, which reportedly increased during physical exercise.

The patient had a sudden onset on August 30, 2018 during a water polo competition, when she developed a swelling in the left shoulder. The swelling extended to the chest and was accompanied by acute pain in the arm, limiting the range of motion in the upper extremity. A day before the competition, the patient had noticed a tingling sensation in her shoulder. During the next 5 days, the patient continued playing for the team. She tried using NSAIDs to relieve pain but the medications did not help much. An ultrasound examination of soft tissues was suggestive of axillary vein thrombosis. The patient was hospitalized for upper left extremity deep vein thrombosis to the Vascular Surgery Unit in her local clinic on September 04, 2018 and discharged home on September 14, 2018. A venous duplex scan performed on admission revealed signs of thrombosis in the axillary, subclavian, brachial and forearm veins, showing no signs of recanalization. During the hospital stay, the patient was receiving anticoagulants (the regimen was not specified in the discharge record). The patient responded to treatment and her edema began to resolve. A venous duplex scan conducted on September 10 revealed signs of early thrombosis recanalization. The patient was screened for hereditary thrombophilia. Polymorphisms were detected in the fibrinogen gene (C10034NT) and the plasminogen activator inhibitor gene (PAl-1). Because the girl was improving, she was 
discharged home. She was also recommended to take diosmin + hesperidin (1000 mg/day), wear compression garments, and make an appointment with a vascular surgeon. In September 2018, the vascular surgeon issued the following prescription: 10 IM injections of sulodexide 600 LSU (1 ampoule a day), followed by a course of oral sulodexide 500 LSU a day. The patient agreed with the recommendations, but went on and off her medications without consulting the doctor, and continued exercising for $2 \mathrm{~h}$ a day.

In June 2019, the patient's condition deteriorated following her stay at a water polo training camp. She noticed that her edema had returned, was growing bigger, and was accompanied by pain. By that time, the patient had discontinued her medications. She was referred to the Federal Research and Clinical Center for Children and Adolescents to rule out recurrent thrombosis and make adjustments to her anticoagulation therapy.

The patient's medical history was unremarkable, with no family history of thrombosis. On examination, the left upper extremity showed no signs of discoloration. There was moderate edema in the shoulder region (the diameter of the affected shoulder differed by $1-15 . \mathrm{cm}$ from the diameter of the contralateral extremity). The infraclavicular fossa appeared full. Peripheral pulses were palpable and symmetrical. Secondary thrombosis associated with rheumatoid diseases (systemic lupus erythematosus, antiphospholipid syndrome), hereditary thrombophilia or connective tissue dysplasia was ruled out.

A triplex ultrasound examination of upper extremity veins conducted on July 7, 2019 revealed no evidence of superficial or deep vein thrombosis or significant venous insufficiency. Coagulation tests were normal: D-dimer $451.0 \mathrm{ng} / \mathrm{ml}$ (reference values < $500 \mathrm{ng} / \mathrm{ml})$; aPTT 29.2 s (24.6-31.2 s); fibrinogen $3.1 \mathrm{~g} / \mathrm{L}$ (1.70-4.20 g/L), antithrombin III 126\% (75-125\%); Quick 100.6\% (70-130\%); thrombin time 20.3 s (15.8-24.9 s); INR 0.99; lupus anticoagulant $41.9 \mathrm{~s}$ (30.4-45.3 s). Natural body anticoagulants: protein S 59.1\% (> 56.10\%) and protein C 130.0\% (70.0-140.0\%); homocysteine $7.5 \mu \mathrm{mol} / \mathrm{L}$ (5.0-12.0 $\mathrm{mmol} / \mathrm{L})$. Autoimmunity tests were negative: antinuclear antibodies (ANA-HEp-2) $1: 80$ (reference values < 1 : 160); anti-double stranded DNA antibodies $1.9 \mathrm{lU} / \mathrm{ml}$ (0-20 IU/ml); IgG cardiolipin antibodies $1.90 \mathrm{IU} / \mathrm{ml}$ (reference values < $20 \mathrm{IU} / \mathrm{ml}$ ); IgM cardiolipin antibodies were not detected; $\beta_{2}$-glycoprotein antibodies (lgG) $2.30 \mathrm{un} / \mathrm{ml}$ (reference values $<5.0 \mathrm{un} / \mathrm{ml}$ ); IgM $\beta_{2}$-glycoprotein antibodies were not detected. In addition, the patient underwent a cervical MRI scan to rule out anatomic abnormalities predisposing to subclavian vein damage.

Having analyzed the patient's medical history and clinical tests (symptoms of acute-onset deep vein thrombosis of the left upper extremity in a professional female athlete due to high training load and an increase in muscle bulk in the shoulder girdle) and ruled out secondary (autoimmunity-associated) thrombosis, we arrived at the diagnosis of Paget-Schroetter syndrome. Angioprotective antithrombotic therapy with sulodexide 500 LSU/day was resumed, and the patient was instructed to follow up with a vascular surgeon. Sports were allowed.

\section{Clinical case discussion}

Secondary deep vein thrombosis (DVT) of the upper extremity is a well-known clinical syndrome. It is common for patients with implanted pacemakers, central venous catheters and cancer. The group of primary DVT disorders is constituted by PSS and thoracic outlet syndrome. The annual incidence of DVT is 1 case per 1,000 population. Upper extremity thrombosis accounts for $4-10 \%$ of DVT cases, of which PSS makes up
$20 \%[2,3]$. Early diagnosis and adequate therapy are crucial to avoiding the life-threatening complication of PSS (pulmonary thromboembolism) and expediting recovery. A metanalysis demonstrated that upper extremity DVT was most commonly observed in baseball players and weightlifters (26.8\% and 19\% of the total 123 DVT cases, respectively); $26.7 \%$ of patients developed pulmonary thromboembolism [4].

At present, DVT is diagnosed based on clinical and instrumental tests. In our case, acute-onset edema and pain in the upper extremity irradiating to the axillary fossa and accompanied by redness were suggestive of acute DVT of the left upper extremity. This provisional diagnosis was later confirmed by an ultrasound scan. Ten months after onset, the teenager was hospitalized to the Federal Research and Clinical Center for Children and Adolescents where the following criteria and risk factors for thrombosis were identified: being a professional athlete (a water polo player), frequent air travel (because of competitions), recurrent injuries during training or competitions, muscle hypertrophy in the upper girdle. Further tests identified risk factors for PSS, including congenital anomalies (a cervical rib), autoimmune diseases increasing the risk of thrombosis, and hereditary thrombophilia.

According to the Russian clinical guidelines on the diagnosis, treatment and prevention of venous thromboembolic complications, patients under the age of 50 should be screened for congenital thrombophilias when thrombosis-inciting events have not been identified or the patient presents with recurrent thromboembolic complications [5]. Polymorphisms detected in the fibrinogen gene (C10034NT) and the plasminogen activator inhibitor gene (PAl-1) are associated with increased risk for thromboembolic complications and indicate that the patient's condition should be closely monitored.

Instrumental tests play the key role in the diagnosis of DVT [2]. Venous Doppler is an accessible, portable and cheap diagnostic test and should be preferred when establishing a preliminary diagnosis. Contrast venography allows a sonographer to visualize all venous lumens in the upper extremity, identify the sites of vein compression by osseous structures, and detect stenosis and fibrotic changes to the subclavian and axillary veins $[6,7]$. Of all non-invasive diagnostic modalities, MRI has the highest sensitivity (100\%) and specificity (97\%). Although venography is not essential for diagnosing DVT, it is almost always performed as part of the multimodal treatment strategy, which includes catheter-directed thrombolysis and surgical decompression [6].

Currently, there is no unified treatment for PSS due to its rarity, the lack of awareness and the absence of large-scale randomized trials [8]. Recommendations given to the patient at her local clinic (14 days of heparin followed by a course of detralex) differed from standard conservative treatment regimens that normally include at least 3 months of anticoagulants [5]. Perhaps, the absence of adequate anticoagulation therapy was the risk factor for the post-thrombotic syndrome developed by our patient.

Among PSS complications are pulmonary embolism, recurrent thrombosis and post-thrombotic syndrome, which occurs in up to $45 \%$ of patients [9]; this urged the development of active treatment strategies with thrombolysis, thrombectomy, percutaneous and surgical venoplasty, venous bypass grafting and stenting. A more aggressive approach (thrombolysis or catheter-directed thrombolysis) surpasses conservative treatment in effectiveness if performed within 2 weeks after the onset of acute thrombosis. According to some authors, early catheter-directed thrombolysis is effective in $75-84 \%$ cases and significantly reduces the risks of post-thrombotic disease and disabilities [10, 11]. 
Our opinion differs from that of the vascular surgeons who decided to put the patient on short-term anticoagulation monotherapy. A study [1] analyzed the outcomes of 41 athletes with upper extremity DVT (44\% of them were female; the mean age was 19 years), including 5 water polo players. PSS was diagnosed in 14 patients; all of them underwent thrombolysis/ anticoagulation therapy followed by a first rib resection. This strategy was successful: $93 \%$ of patients were able to return to professional sports within an average of 4.6 months after surgery. Only 2 patients (14\%) relapsed.

\section{References}

1. Chandra V, Little C, Lee JT. Thoracic outlet syndrome in highperformance athletes. J Vasc Surg. 2014 Oct; 60 (4): 1012-7; DOI: 10.1016/j.jvs.2014.04.013. Epub 2014 May 14. PMID: 24835692.

2. Hangge P, Rotellini-Coltvet L, Deipolyi AR, Albadawi H, Oklu R. Paget-Schroetter syndrome: treatment of venous thrombosis and outcomes. Cardiovasc Diagn Ther. 2017; 7 (Suppl 3): 285-90. DOI: $10.21037 /$ cdt.2017.08.15.

3. Heil J, Miesbach W, VogI T, Bechstein WO, Reinisch A. Deep Vein Thrombosis of the Upper Extremity. Dtsch Arztebl Int. 2017; 114 (14): 244-9. DOI: 10.3238/arztebl.2017.0244.

4. Keller RE, Croswell DP, Medina GIS, Cheng TTW, Oh LS. PagetSchroetter syndrome in athletes: a comprehensive and systematic review. J Shoulder Elbow Surg. 2020 Nov; 29 (11): 2417-25. DOI: 10.1016/j.jse.2020.05.015. Epub 2020 Jun 9. PMID: 32868012.

5. Rossijskie klinicheskie rekomendacii po profilaktike i lecheniju venoznyh trombojembolicheskih oslozhnenij (VTJeO). Flebologija. 2015; 2: 4-52.

6. Phadke DR, Sheeran DP, Wilkins LR, Kern JA, Tracci MC, Angle JF. Impact of Venous Collaterals on Clinical Outcomes in PagetSchroetter Syndrome. J Vasc Interv Radiol. 2019; 30: 572-7. DOI: 10.1016/j.jvir.2018.12.0

\section{Литература}

1. Chandra V, Little C, Lee JT. Thoracic outlet syndrome in highperformance athletes. J Vasc Surg. 2014 Oct; 60 (4): 1012-7; DOI: 10.1016/j.jvs.2014.04.013. Epub 2014 May 14. PMID: 24835692.

2. Hangge P, Rotellini-Coltvet L, Deipolyi AR, Albadawi H, Oklu R. Paget-Schroetter syndrome: treatment of venous thrombosis and outcomes. Cardiovasc Diagn Ther. 2017; 7 (Suppl 3): 285-90. DOI: $10.21037 /$ cdt.2017.08.15.

3. Heil J, Miesbach W, VogI T, Bechstein WO, Reinisch A. Deep Vein Thrombosis of the Upper Extremity. Dtsch Arztebl Int. 2017; 114 (14): 244-9. DOl: 10.3238/arztebl.2017.0244.

4. Keller RE, Croswell DP, Medina GIS, Cheng TTW, Oh LS. PagetSchroetter syndrome in athletes: a comprehensive and systematic review. J Shoulder Elbow Surg. 2020 Nov; 29 (11): 2417-25. DOl: 10.1016/j.jse.2020.05.015. Epub 2020 Jun 9. PMID: 32868012.

5. Российские клинические рекомендации по профилактике и лечению венозных тромбоэмболических осложнений (ВТЭО). Флебология. 2015; 2: 4-52.

6. Phadke DR, Sheeran DP, Wilkins LR, Kern JA, Tracci MC, Angle JF. Impact of Venous Collaterals on Clinical Outcomes in PagetSchroetter Syndrome. J Vasc Interv Radiol. 2019; 30: 572-7. DOI: 10.1016/j.jvir.2018.12.0.

\section{CONCLUSION}

Raising awareness about the risk of thrombosis in the described cohort of patients among primary and emergency health care providers will facilitate early diagnosis and timely treatment; such patients should be referred to a vascular or thoracic surgeon for thrombolysis or surgery. Further research should explore the advantages of thrombolytic therapy in cases of diagnostic delay, identify factors that render thrombolysis ineffective and raise the need for surgery.

7. Bosch FTM, Nisio MD, Büller HR, van Es N. Diagnostic and therapeutic management of upper extremity deep vein thrombosis. J Clin Med. 2020; 9 (7): 2069. DOl: 10.3390/jcm9072069.

8. Thiyagarajah K, Ellingwood L, Endres K, Hegazi A, Radford J, lansavitchene $A_{\text {., }}$ et al. Post-thrombotic syndrome and recurrent thromboembolism in patients with upper extremity deep vein thrombosis: A systematic review and meta-analysis. Thromb Res. 2019; 174: 34-39. DOI: 10.1016/j.thromres.2018.12.012.

9. Bleker SM, van Es N, Kleinjan A, Büller HR, Kamphuisen PW, Aggarwal $A$, et al. Current management strategies and longterm clinical outcomes of upper extremity venous thrombosis. J Thromb Haemost. 2016 May; 14 (5): 973-81. DOI: 10.1111/ jth.13291. Epub 2016 Apr 4. PMID: 26866515.

10. Moore R, Wei Lum Y. Venous thoracic outlet syndrome. Vasc Med. 2015 Apr; 20 (2): 182-9. DOI: 10.1177/1358863X14568704. PMID: 25832605

11. Mazajshvili KV, Darvin W, Klimova NV, Kabanov AA, Lobanov DS, Mozhanova GA. Klinicheskij sluchaj uspeshnogo selektivnogo kateternogo trombolizisa pri sindrome Pedzheta-Shrettera. Vestnik SurGU. Medicina. 2018; 4 (38): 28-32.

7. Bosch FTM, Nisio MD, Büller HR, van Es N. Diagnostic and therapeutic management of upper extremity deep vein thrombosis. J Clin Med. 2020; 9 (7): 2069. DOI: 10.3390/jcm9072069.

8. Thiyagarajah K, Ellingwood L, Endres K, Hegazi A, Radford J, lansavitchene A., et al. Post-thrombotic syndrome and recurrent thromboembolism in patients with upper extremity deep vein thrombosis: A systematic review and meta-analysis. Thromb Res. 2019; 174: 34-39. DOI: 10.1016/j.thromres.2018.12.012.

9. Bleker SM, van Es N, Kleinjan A, Büller HR, Kamphuisen PW, Aggarwal $A$, et al. Current management strategies and longterm clinical outcomes of upper extremity venous thrombosis. J Thromb Haemost. 2016 May; 14 (5): 973-81. DOI: 10.1111/ jth.13291. Epub 2016 Apr 4. PMID: 26866515.

10. Moore R, Wei Lum Y. Venous thoracic outlet syndrome. Vasc Med. 2015 Apr; 20 (2): 182-9. DOI: 10.1177/1358863X14568704. PMID: 25832605

11. Мазайшвили К. В., Дарвин В. В., Климова Н. В., Кабанов А. А., Лобанов Д. С., Можанова Г. А. Клинический случай успешного селективного катетерного тромболизиса при синдроме Педжета-Шреттера. Вестник СурГУ. Медицина. 2018; 4 (38): 28-32. 